\title{
Candesartan mediates microcirculation in acute necrotizing pancreatitis
}

\author{
Bostanci $\mathrm{H}^{1}$, Sahin $\mathrm{TT}^{2}$, Dikmen $\mathrm{K}^{1}$, Dikmen AU ${ }^{5}$, Yuksel $\mathrm{O}^{1}$, Gulbahar $\mathrm{O}^{3}$, Poyraz A ${ }^{4}$, Tekin E ${ }^{1}$
}

Gazi University Faculty of Medicine, Department of Surgery, Besevler, Ankara, Turkey. hasanbostanci@yahoo.com

\begin{abstract}
Aim: In the present study we aimed to determine the effect of an AT-II antagonist candesartan on pancreatic microcirculation in an experimental model of acute necrotizing pancreatitis.

Materials and methods: There were five study groups with 10 animals in each. Pancreatitis was induced by intravenous infusion of cerulein and coadministration of glycodeoxycholate into biliopancreatic canal. Candesartan is given at 6th and 18th hour to the 24th and 48th hour groups, respectively. At 24th and 48th hours; following anaesthesia laparotomy was performed and laser Doppler flowmetry was performed in the pancreatic tissue of the animals. Following scarification blood samples were obtained for amylase, myeloperoxidase, IL- 6 and tumour necrosis factor alpha. Tissue samples from the pancreas were obtained for histopathological analysis, endothelial cell apoptosis (TUNEL assay) and matrix metalloproteinase- 9 immunohistochemistry.

Results: Pancreatic microcirculation was higher in the candesartan treated groups $(p<0.05)$. Myeloperoxidase, IL-6 and tumour necrosis factor alpha was found to be lower in the candesartan treated groups $(p<0.05)$. The pancreatic edema and inflammation were found to be reduced in the candesartan treated groups $(p<0.05)$. Endothelial apoptosis was found to be reduced by cadesartan treatment but it did not reach statistical significance $(p>0.05)$. Tissue matrix metalloproteinase -9 levels were found to be reduced with candesartan treatment $(p<0.05)$.

Conclusion: Treatment with candesartan in the early phases of acute necrotizing pancreatitis effective on microcirculation of pancreatic tissue (Tab. 3, Fig. 6, Ref. 28). Text in PDF www.elis.sk.

Key words: acute necrotizing pancreatitis, microvascular circulation, candesartan, matrix metalloproteinase.
\end{abstract}

\section{Introduction}

Microcirculatory dysfunction in the pancreas seems to have a critical role in the evolution of acute pancreatitis (1). The pathophysiological changes of pancreatic microcirculation in acute pancreatitis (AP) are complex; they include vasoactive mediators, vasoconstriction, ischemia, etc. (2). There is considerable evidence supporting ischemia as an initiating factor of pancreatic microcirculatory injury (3). The vasoconstriction occurring in the early phase of AP may cause ischemia and stasis of the microcirculation (4).

Matrix metalloproteinases (MMP) are effective in the late phase of the inflammatory cascade. The MMP family is a group of zinc endopeptidases with different specificities for substrates

${ }^{1}$ Gazi University Faculty of Medicine, Department of Surgery, Besevler, Ankara, Turkey, ${ }^{2}$ Hacettepe University Faculty of Medicine, Department of Surgery, Sihiyye, Ankara, Turkey, ${ }^{3}$ Gazi University Faculty of Medicine, Department of Biochemistry, Besevler, Ankara, Turkey, ${ }^{4}$ Gazi University Faculty of Medicine, Department of Pathology, Besevler, Ankara, Turkey, and ${ }^{5}$ Gazi University Faculty of Medicine, Department of Public Health, Besevler, Ankara, Turkey

Address for correspondence: $\mathrm{H}$. Bostanci, MD, Gazi University Faculty of Medicine, Department of Surgery, Gazi University Faculty of Medicine Department of General Surgery 06500 Besevler, Ankara, Turkey. Phone: +905322064087, Fax: +903123092958

Acknowledgement: This study was supported by Gazi University Research Foundation (01/2007-24). of the extracellular matrix. A subgroup of these enzymes, which includes the type IV collagenases MMP-9 (gelatinase B) or MMP-2 (gelatinase A), has been shown to degrade some basement membrane components (5). Neutrophils produce MMP on stimulation with trypsin being abundant in AP (6).

The existence of an intrinsic renin-angiotensin system (RAS) in the pancreas has been previously suggested in the canine (7). Angiotensin-I (AT1) and angiotensin-II (AT2) have been localized by immunochemistry to the endothelia and epithelia of the pancreatic vasculature and ductal system in the rodent pancreas. The pancreatic RAS may play a role for the regulation of pancreatic microcirculation and ductal secretion (8). Angiotensin converting enzyme (ACE) inhibitors increase levels of the vasodilatory prostaglandins and nitric oxide which may be involved in the protective mechanism (9).

In the present study, we assessed the effects of candesartan, an AT2 receptor antagonist, on pancreatic microcirculatory disorders and MMPs in the severity AP in rats.

\section{Materials and methods}

\section{Animal models}

We used 50 female Sprague Dawley rats weighing 280-340 g, housed in rooms maintained at $21 \pm 1{ }^{\circ} \mathrm{C}$ and a 12-h dark cycle. Animals fasted overnight $(12 \mathrm{~h})$ before the experiment but had free access to water. Care was provided in accordance with the 
guidelines set by the ethics committee of Gazi University, Ankara, Turkey. Anasthesia was induced with intramuscular injection of ketamine $(50 \mathrm{mg} / \mathrm{kg}$; Ketalar, ECZACIBASI, Turkey) and intramuscular injection of xylazine hydrochloride ( $5 \mathrm{mg} / \mathrm{kg}$; Rompun, BAYER; Germany). The right internal jugular vein was cannulated and the catheter was tunneled subcutaneously to the suprascapular area. Acute pancreatitis was induced by an intravenous infusion of cerulein (SIGMA ALDRICH; Germany) at $5 \mu \mathrm{g} / \mathrm{kg} / \mathrm{h}$ over $6 \mathrm{~h}$ superimposed on a standard infusion of $1.2 \mathrm{~mL} / \mathrm{kg}$ glycodeoxycholic acid (10 mmol/L; SIGMAALDRICH; GermanyY) into the biliary-pancreatic duct for $10 \mathrm{~min}$ at $30 \mathrm{~mm} \mathrm{Hg}(10)$.

\section{Experimental protocol}

The animals were randomly allocated into five groups: Group I $(\mathrm{n}=10)$, sham; Group II $(\mathrm{n}=10), 24 \mathrm{~h}$ control group; Group III $(\mathrm{n}=10), 48 \mathrm{~h}$ control group; Group IV $(\mathrm{n}=10), 24 \mathrm{~h}$ candesartan group; Group V $(\mathrm{n}=10), 48 \mathrm{~h}$ candesartan group. Animals in the 24 and $48 \mathrm{~h}$ control group were administered $2.5 \mathrm{~mL}$ saline orally via gavage method at 6 and $18 \mathrm{~h}$ following the induction of ANP, whereas animals in the 24 and $48 \mathrm{~h}$ candesartan group were administered a $2.5 \mathrm{~mL}$ of solution that contained $10 \mathrm{mg} / \mathrm{kg}$ candesartan orally via gavage method at 6 and $18 \mathrm{~h}$ following the induction of ANP. On day 1, the rats of $24 \mathrm{~h}$ control and $24 \mathrm{~h}$ candesartan groups and on day 2 , the rats of $48 \mathrm{~h}$ control and 48 $\mathrm{h}$ candesartan groups were anesthetized and a re-laparatomy was performed. Pancreatic blood flow was measured in three different parts of pancreas by using laser Doppler flowmeter (Perimed; Sweden). The mean values were calculated and presented as percent changes from basal values obtained in control rats (100\%). After the measurements blood was aspirated from the inferior caval vein for amylase, myeloperoxidase (MPO), IL-6 and tumor necrosis factor alpha (TNF- $\alpha$ ). The pancreatic tissue was removed for microscopic evaluation and the animals were exsanguinated.

\section{Biochemical analysis}

Pancreatic amylase levels were measured using the ELISA kit (Immundiagnostic, Germany), IL-6 levels were measured by IL-6 ELISA kit (Biosource, Belgium), serum MPO levels were measured by ELISA kit (Hycult, Netherlands) and levels of TNF- $\alpha$ were measured via the use of the ELISA kit (Biosource, USA); all were according to the the protocol provided by the particular company.

\section{Histopathological analysis}

A portion of the pancreatic tissue from each rat was fixed in $10 \%$ neutral buffered formalin and embedded in paraffin. One paraffin section, stained with hematoxylin and eosin (H\&E), was examined from each animal. One pathologist who was blinded to the treatment protocol scored the tissues for edema, acinar necrosis, inflammatory infiltrate, hemorrhage, fat necrosis, and perivascular inflammation, in 20 different fields. The scores for each of the histologic abnormalities were added up (11).

\section{Endothelial cells apoptosis}

Additional sections were prepared to establish the degree of endothelial cell apoptosis. The tissue samples were stained by the terminal deoxynucleotidyl transfer-mediated dUTP-biotin nick end labelling (TUNEL) method. The TUNEL assay for apoptotic cell detection was performed using the I.S. Cell Death Detection Kit (Chemicon; USA). Briefly, $5 \mathrm{~mm}$ thick paraffin embedded sections were incubated at $56{ }^{\circ} \mathrm{C}$ overnight. Following deparaffinization and inactivation of endogenous peroxidase with $3 \%$ hydrogenperoxidase, the slides were incubated with $20 \mathrm{mg} / \mathrm{mL}$ proteinase $\mathrm{K}$ (Sigma-Aldrich; Germany) for $15 \mathrm{~min}$. The following steps were performed according to the manufacturer's instructions of TUNEL assay using Apoptag plus peroxidase in situ apoptosis detection. Finally, the slides were incubated with diaminobenzidine. Counterstaining of the specimens was done with $1 \%$ methyl green for $10 \mathrm{~min}$. Macrophages within germinal centre of tonsil were used as positive control. Each specimen was evaluated in light microscopy at high magnification (x400). TUNEL positive cells were counted (12). A qualified pathologist blinded to the source of pancreatic tissue performed all measurements.

Immunohistochemical examination of pancreatic tissue MMP-9

$4 \mu \mathrm{m}$ paraffin embedded pancreatic section was deparafinized, mounted on poly-L-lysine-coated glass slides, and rehydrated in PBS. Endogenous peroxidase activity was blocked by incubation with $3 \% \mathrm{H}_{2} \mathrm{O}_{2} / \mathrm{PBS}$ for $10 \mathrm{~min}$. After being immersed in goat serum blocking buffer at $37{ }^{\circ} \mathrm{C}$ for 1 hour, the specimens were incubated with mouse anti-rat MMP-9 monoclonal antibody at 4 ${ }^{\circ} \mathrm{C}$ overnight. The specimens were incubated with biotin conjugated goat anti-mouse secondary for 2 hours at room temperature, and then were incubated with $\mathrm{ABC}$ for $30 \mathrm{~min}$. Finally,colouring reaction was performed with 3,3-diaminobenzidine and haematoxylin nucleus counter staining. Random observation of 5 high power microscopic views was used to evaluate staining results in each group. Brown staining cells were defined as MMP-9 positive expression cells (13).

\section{Statistical analysis}

Statistical analysis was carried out using the SPSS 11.5 statistical program. The data are expressed as the mean \pm SD. Statistical analysis of biochemical and histopathologic parameters was performed using the nonparametric Kruskal-Wallis $\mathrm{H}$ test, followed by the corrected Mann-Whitney U test, with a $\mathrm{p}$ value less than 0.05 considered to be statistically significant.

\section{Results}

\section{Microcirculatory values}

Administration of candesartan significantly improved the microcirculation of the pancreas in treated groups $(\mathrm{p}<0.05)$ (Tab. 1, Fig. 1).

\section{Biochemical analysis}

Pancreatic amylase levels in the control and candesartan groups were significantly higher than in the sham group $(\mathrm{p}<0.05)$ (Tab. 1). Serum MPO levels in the $24 \mathrm{~h}$ and $48 \mathrm{~h}$ candesartan groups were significantly higher than $24 \mathrm{~h}$ and $48 \mathrm{~h}$ control groups $(\mathrm{p}<$ 0.05 ) (Tab. 1, Fig. 2). Acute necrotizing pancreatitis caused a sig- 
Tab. 1. Microcirculatory values in pancreatic tissue and biochemical parameters ( \pm standard deviation).

\begin{tabular}{|c|c|c|c|c|c|}
\hline & $\begin{array}{c}\text { Sham } \\
(\mathrm{n}=10)\end{array}$ & $\begin{array}{l}24 \text { Control } \\
(\mathrm{n}=10)\end{array}$ & $\begin{array}{l}48 \text { Control } \\
(\mathrm{n}=10)\end{array}$ & $\begin{array}{c}24 \text { Candesartan } \\
(\mathrm{n}=10)\end{array}$ & $\begin{array}{c}48 \text { Candesartan } \\
(\mathrm{n}=10)\end{array}$ \\
\hline$\overline{M(\%)}$ & $100 \pm 9$ & $43.4 \pm 4^{*}$ & $34.4 \pm 3^{*}$ & $96 \pm 7 * \#$ & $94 \pm 6^{* \#}$ \\
\hline Amylase (mU/L) & $851.1 \pm 243.5$ & $1660.2 \pm 676.1^{*}$ & $942.1 \pm 1018.5$ & $1623.0 \pm 1057.7 *$ & $1000 \pm 1069$ \\
\hline MPO (ng/mL) & $114.2 \pm 23.0$ & $267.8 \pm 37.1 *$ & $306.7 \pm 34.4 *$ & $165.1 \pm 58.8 * \#$ & $182.8 \pm 87.9 * \#$ \\
\hline IL-6 (pg/mL) & $41.5 \pm 31.8$ & $250.1 \pm 242.1 *$ & $573.0 \pm 1182.1^{*}$ & $96.1 \pm 84.7 \#$ & $131.3 \pm 94.4^{* \#}$ \\
\hline $\mathrm{TNF}-\alpha(\mathrm{pg} / \mathrm{mL})$ & $13.1 \pm 7.1$ & $40.2 \pm 27.5^{*}$ & $123.8 \pm 170.6^{*}$ & $23.3 \pm 10.0 \#$ & $58.1 \pm 62.9 * \#$ \\
\hline
\end{tabular}

$\mathrm{M}$ - Microcirculation, MPO - Myeloperoxidase, IL - Interleukin, TNF - Tumor necrosis factor alpha, $* \mathrm{p}<0.05$; Control and candesartan groups vs sham group, \# $<0.05$; 24 and 48 control groups vs 24 and 48 candesartan groups

Tab. 2. Pancreatic injury ( \pm standard deviation).

\begin{tabular}{|c|c|c|c|c|c|}
\hline Injury parameters & $\begin{array}{l}\text { Sham } \\
(n=10)\end{array}$ & $\begin{array}{l}24 \text { Control } \\
(\mathrm{n}=10)\end{array}$ & $\begin{array}{c}48 \text { Control } \\
(\mathrm{n}=10)\end{array}$ & $\begin{array}{c}24 \text { Candesartan } \\
(\mathrm{n}=10)\end{array}$ & $\begin{array}{c}48 \text { Candesartan } \\
(\mathrm{n}=10)\end{array}$ \\
\hline Edema & $0.75 \pm 0.75$ & $1.87 \pm 1.18^{*}$ & $2.06 \pm 0.86^{*}$ & $0.87 \pm 0.44 * \#$ & $1.37 \pm 0.69 * \#$ \\
\hline Acinar cell degeneration & 0 & $0.60 \pm 0.88$ & $1.12 \pm 1.32$ & $0.40 \pm 0.70$ & $0.50 \pm 0.92$ \\
\hline Necrosis & 0 & $0.81 \pm 1.19$ & $0.93 \pm 1.14$ & $0.31 \pm 0.70$ & $0.81 \pm 1.03$ \\
\hline İnflammation & $0.06 \pm 0.17$ & $0.87 \pm 0.58 *$ & $2.25 \pm 1.51 *$ & $0.62 \pm 1.27 * \#$ & $0.93 \pm 0.97 * \#$ \\
\hline
\end{tabular}

$* \mathrm{p}<0.05$; Control and candesartan groups vs sham group, $\# \mathrm{p}<0.05 ; 24$ and 48 control groups vs 24 and 48 candesartan groups

Tab. 3. Endothelial cell apoptosis and MMP-9 in pancreatic tissue ( \pm standard deviation).

\begin{tabular}{|c|c|c|c|c|c|}
\hline & $\begin{array}{c}\text { Sham } \\
(n=10)\end{array}$ & $\begin{array}{l}24 \text { Control } \\
(\mathrm{n}=10)\end{array}$ & $\begin{array}{l}48 \text { Control } \\
(\mathrm{n}=10)\end{array}$ & $\begin{array}{c}24 \text { Candesartan } \\
(\mathrm{n}=10)\end{array}$ & $\begin{array}{l}48 \text { Candesartan } \\
(\mathrm{n}=10)\end{array}$ \\
\hline Apoptosis (cell $/ \mathrm{mm}^{2}$ ) & $1 \pm 0.2$ & $2 \pm 0.75$ & $3 \pm 1.25$ & $2 \pm 0.25$ & $1 \pm 0.50$ \\
\hline \multicolumn{6}{|l|}{ MMP-9 } \\
\hline- & 8 & 8 & $1 *$ & 9 & 7 \\
\hline+ & 2 & 1 & $2 *$ & 1 & 2 \\
\hline++ & - & 1 & $3 *$ & - & 1 \\
\hline+++ & - & - & $4 *$ & - & - \\
\hline
\end{tabular}

MMP-9 - Matrix metalloproteinase-9, ${ }^{*} \mathrm{p}<0.05 ; 48$ control group vs sham, 24 control, 24 candesartan and 48 candesartan groups

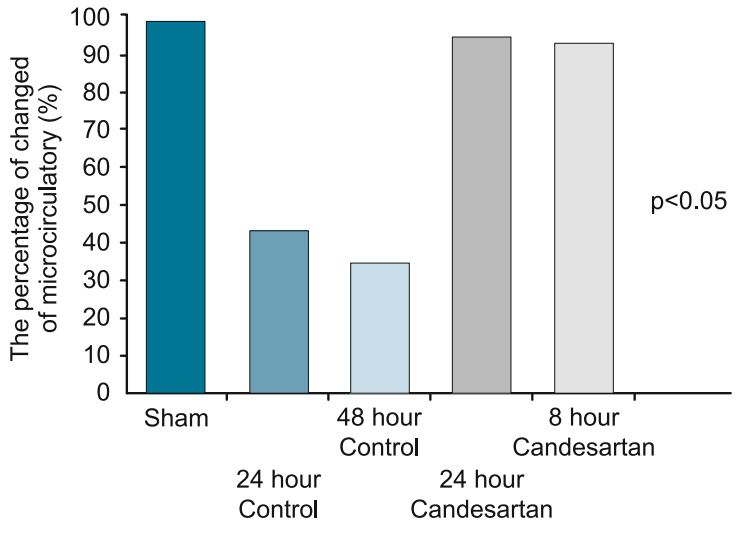

Fig. 1. Microcirculatory values in pancreatic tissue.

nificant increase of serum IL-6 activity. Candesartan administration significantly decreased this parameter in candesartan groups $(p<0.05)$ (Tab. 1, Fig. 3). Acute necrotizing pancreatitis caused a significant increase of serum TNF- $\alpha$ level. Candesartan administration significantly decreased this parameter in candesartan treated groups $(\mathrm{p}<0.05)$ (Tab. 1, Fig. 4).

\section{Histopathological analysis}

The results of histopathologic analysis of pancreatic tissue for damage yielded that in the control groups it was higher compared with candesartan treated groups (both, $\mathrm{p}<0.05$ ). Histo-

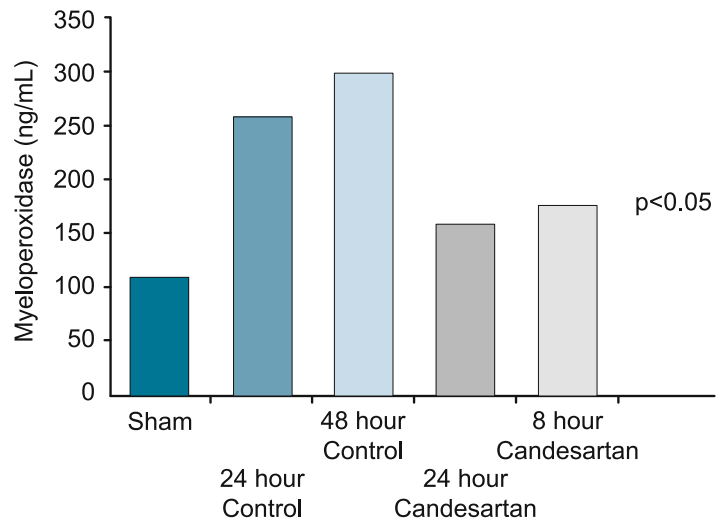

Fig. 2. Myeloperoxidase levels.

pathologic findings are summarized in Table 2 and Figures 5A and $5 \mathrm{~B}$.

\section{Endothelial cells apoptosis}

Endothelial apoptosis was found to be reduced by cadesartan treatment but it did not reach statistical significance $(\mathrm{p}>0.05)$ (Tab. 3).

\section{Pancreatic tissue MMP-9}

Tissue MMP-9 levels were found to be reduced with candes$\operatorname{artan}$ treatment $(\mathrm{p}<0.05)$ (Tab. 3, Fig. 6). 


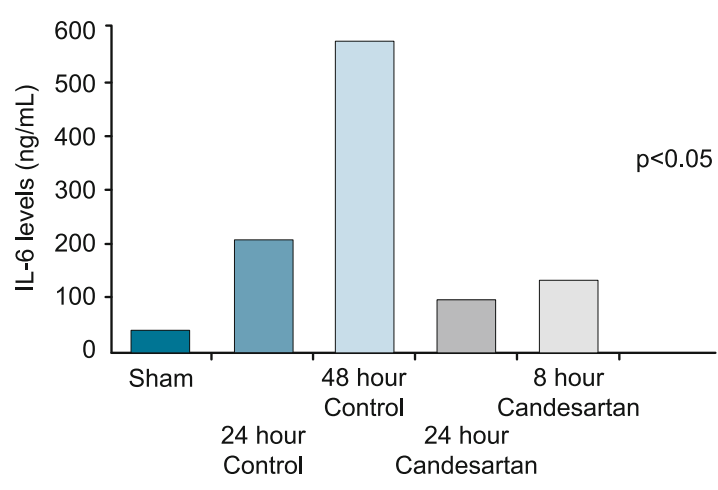

Fig. 3. IL-6 levels.
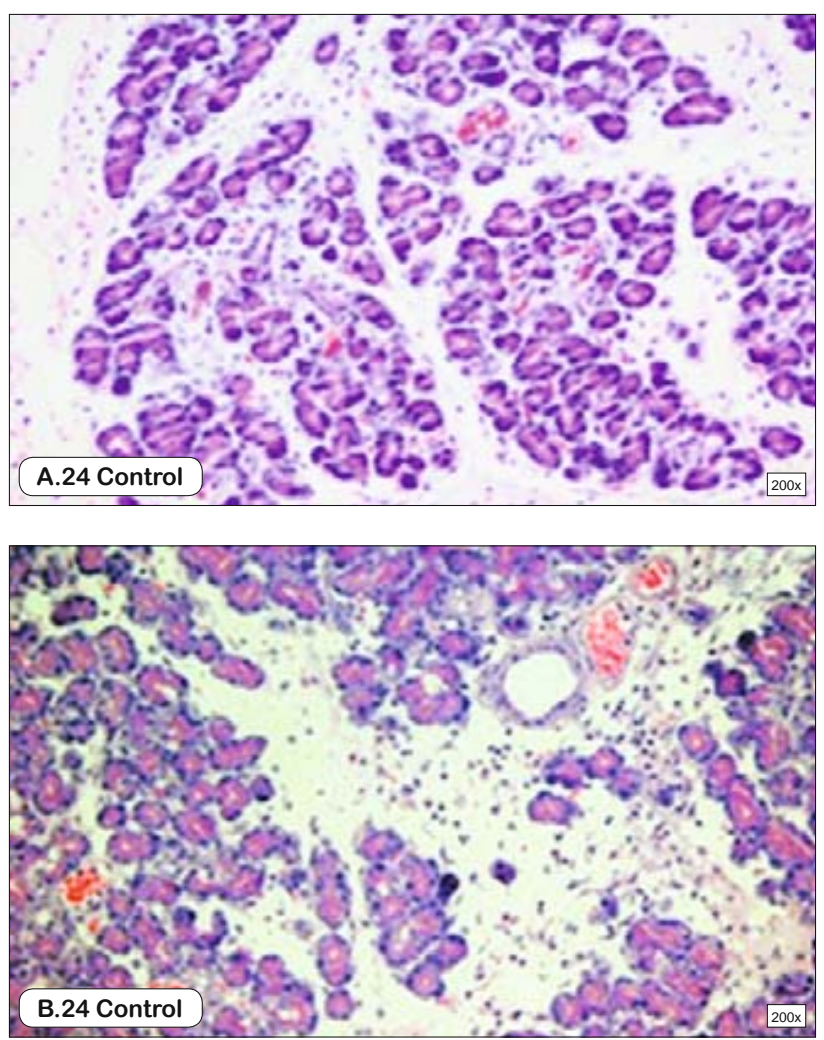

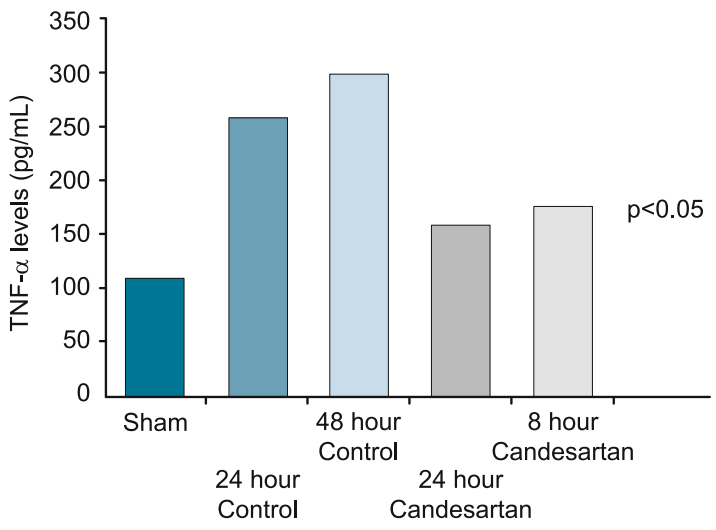

Fig. 4. TNF- $\alpha$ levels.
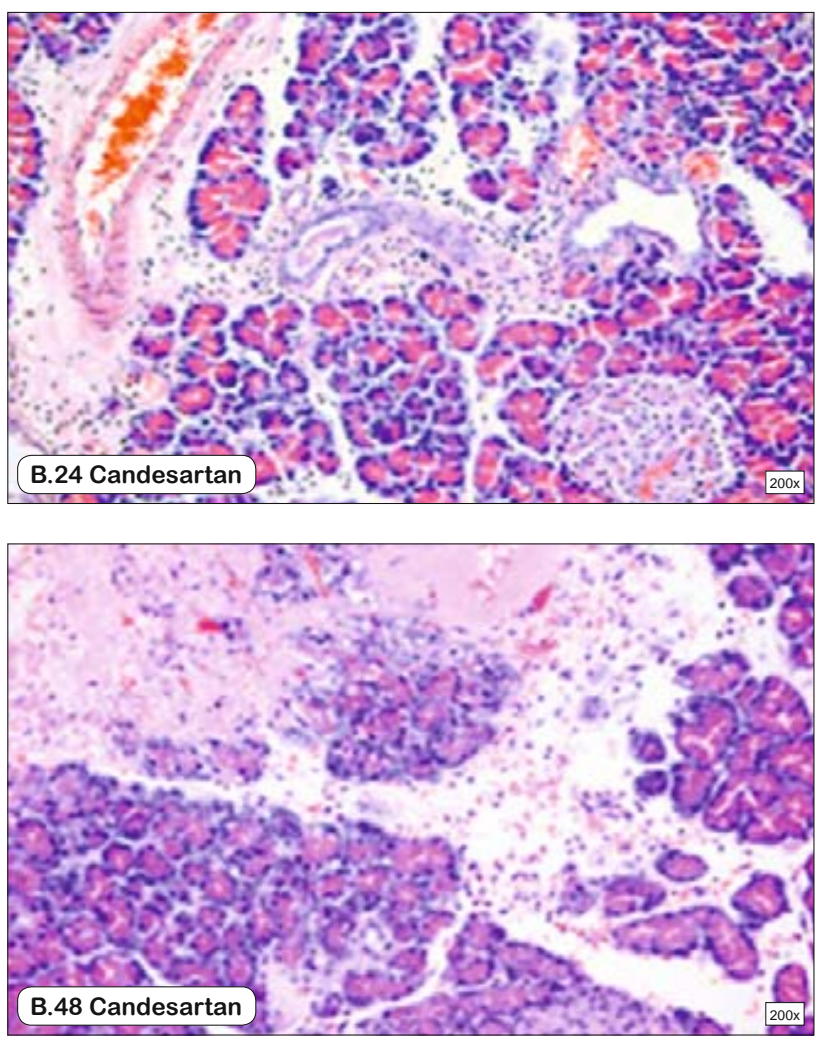

Fig. 5. Histopathologic features in different groups in pancreatic tissue. (A) Extensive necrosis, intense edema, inflammatory infiltrate, and hemorrhage in 24 and 48 control groups (H\&E, x200). (B) Mild necrosis, mild edema, slight infiltration by inflammatory cells and slight hemorrhage in 24 and 48 candesartan groups $(H \& E$, x200).

\section{Discussion}

Today the pathogenesis of acute pancreatitis is understood as a disturbance of acinar cell integrity with local inflammation, followed by a release of proinflammatory mediators into the circulation. By this, the local inflammatory process triggers a systemic inflammatory reaction (14). The release of proinflammatory cytokines results into the activation of endothelial cells and increases the expression of adhesion molecules. Subsequently, pancreatic microcirculatory disorder with reduced parenchymal blood flow and increased leukocyte-endothelial interaction enables leukocyte extravasation into the tissue (15). Microcirculatory disturbances are crucial in the progression of mild edematous to severe necrotizing pancreatitis and are accurate parameters for evaluating the severity of the disease (16). Microcirculatory disturbances in AP comprise many components: decreased capillary blood flow and capillary density, increased capillary permeability, and enhanced leukocyte-endothelial interactions (17). It is still not clear which 


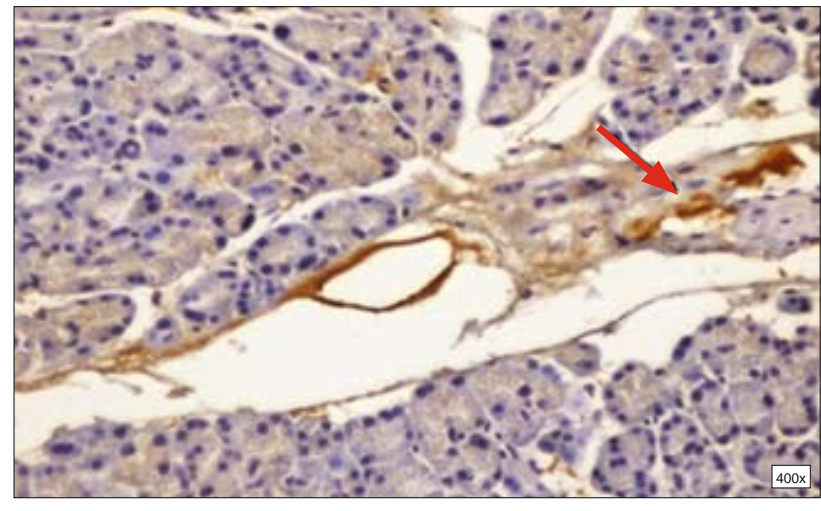

Fig. 6. Immunohistochemical localization of MMP-9 expression in pancreatic tissue (x400) (48 control group).

of these factors is the initiating one or the most important. The improvement of pancreatic microperfusion should have a positive influence on microscopic alterations within the pancreas. Many reagents have been used for microcirculatory disorders. However the use of these substances in the clinical practice is limited. In the present study we aimed to determine the effect of an AT-II antagonist candesartan on pancreatic microcirculation in an experimental model of acute necrotizing pancreatitis.

Capillary perfusion is altered further by changes in regional blood flow. Laser Doppler flowmetry has shown progressive exclusion of capillaries from perfusion. The consequence of AP in rats was the reduction of capillary blood flow in the pancreas (18). In this study pancreatic blood flow was measured by a laser Doppler flowmeter and confirms these data. Candesartan administration significantly augmented capillary blood perfusion of pancreatic tissue.

Amylase is released from acinar cells during acute pancreatitis, and concentration in the serum is used to confirm the diagnosis of pancreatitis (19). In the present study the amylase levels were higher in the $24 \mathrm{~h}$ control and $24 \mathrm{~h}$ candesartan groups than other groups.

Pancreatic MPO activity, an indirect index of granulocyte infiltration, was significantly decreased in the candesartan treated groups. These results suggest that candesartan treatment in AP may reduce tissue destruction, proinflammatory cytokine response and pancreatic damage.

The serum marker IL- 6 reflects the severity of pancreatitis in the early course of the disease (20). Pancreatic necrosis has been shown to increase the circulating levels of cytokines such as IL-6 (21). In the present study, it was observed that IL-6 levels were significantly higher in control groups. These results show that candesartan treatment may reduce pancreatic necrosis by improving pancreatic microcirculatory disorders in AP.

TNF plays a key role and is an important parameter that indicates the severity of AP (22). It is known to mediate tissue damage through the activation of inflammatory cells, upregulation of adhesion molecules, the production of nitric oxide, and the release of other cytokines and mediators of inflammation (23). Improving the pancreatic capillary blood flow may regulate proinflammatoryantiinflammatory response. We demonstrated that administration of candesartan in AP may increase pancreatic capillary blood flow and decrease activation of inflammatory cells.

Acute pancreatitis is characterized by interstitial edema, vacuolization, inflammation, and acinar cell necrosis (24). Architectural changes to the microcirculation are also detectable within $30 \mathrm{~min}$ of the onset of inflammation (25). Histological changes in animal pancreatitis parallel findings in humans. Microscopy demonstrates vessel wall media necrosis, with infiltration of polymorphonuclear leukocytes, increased fenestration, micropinocytic vesicles and irregularity of the endothelial lining (26). Improvement of microcirculatory disorders may reduce injury of the pancreatic tissue. In this study, administration of candesartan in AP reduced edema, inflammation and acinar cell necrosis in pancreatic tissue.

The accumulation of inflammatory cells and the release of inflammatory factors after the occurrence of pancreatitis are factors that influence the disease process. There are many studies that support the fact that there is a close relationship between the apoptosis of pancreatic acinar cells and the severity of acute pancreatitis (27). In our study the elevated apoptosis also closely correlated with the improvement of pancreatic blood flow. The results from our experiment support that apoptosis may change with improvement of pancreatic microcirculatory blood flow.

The inhibition of MMP-9 expression may lead to decrease granulocyte infiltration and reduced exacerbated inflammatory reaction in AP (15). Our study has shown that candesartan decreases pancreatic tissue MMP-9 expression.

Consistent with our study, upregulation of pancreatic angiotensinogen may have a role for the regulation of tissue injury (28). Inhibition of the $\mathrm{AT}_{2}$ receptor could play a crucial role in the induction of inflammation and in the impairment of microcirculatory regulation in the pancreas. Candesartan plays an important role in preventing the development and progression of acute necrotizing pancreatitis.

In conclusion; more dynamic and functional therapies should be developed that takes in to consideration the process of inflammation and tissue damage. The $\mathrm{AT}_{2}$ pathway seems to play central role in mediation of inflammation, tissue damage and fibrosis; all of which are central in the pathogenesis of acute necrotizing pancreatitis. Therefore the results of the present study should be confirmed with further studies and further by multicenter clinical trials.

\section{References}

1. Menger MD, Pluscxyk T, Vollmar B. Microcirculatory derangements in acute pancreatitis. J Hepatobiliary Pancreat Surg 2001; 8: 187-194.

2. Zhou ZG, Chen YD, Sun W, Chen Z. Pancreatic microcirculatory impairment in experimental acute pancreatitis in rats. World J Gastroenterol 2002; 8: 933-936.

3. Sendur R, Pawlik WW. Vascular factors in the mechanism of acute pancreatitis. Przegl Lek 1996; 53: 41-45.

4. Skoromnyi AN, Starosek VN. Hemodynamic changes in the liver, kidney, small intestine and pancreas in experimental acute pancreatitis. Klin Khir 1998; 12: 46-48.

5. Keck T, Balcom JH, Fernández-del Castillo C, Antoniu BA, Warshaw AL. Matrix metalloproteinase-9 promotes neutrophil migration and 
alveolar capillary leakage in pancreatitis-associated lung injury in the rat. Gastroenterology 2002; 122: 188-201.

6. Mikami Y, Dobschütz EV, Sommer O et al. Matrix metalloproteinase-9 derived from polymorphonuclear neutrophils increases gut barrier dysfunction and bacterial translocation in rat severe acute pancreatitis. Surgery 2009; 145: 147-156.

7. Chappell MC, Millsted A, Diz DI, Brosnihan KB, Ferrario CM. Evidence for an intrinsic angiotensin system in the canine pancreas. $\mathrm{J}$ Hypertens 1991; 9: 751-759.

8. Leung PS, Chan WP, Nobiling R. Regulated expression of pancreatic renin-angiotensin system in experimental pancreatitis. Mol Cell Endocrinol 2000; 166: 121-128.

9. Schaefer KL, Porter JA. Angiotensin II receptor antagonists: the prototype losartan. Ann Pharmacother 1996; 30: 625-636.

10. Schmidt J, Rattner MD, Lewandrowski K. A better model of acute pancreatitis for evaluating therapy. Ann Surg 1992; 215: 44-56.

11. Esrefoglu M, Gül M, Ates B, Batcioglu K, Selimoglu MA. Antioxidative effect of melatonin, ascorbic acid and $\mathrm{N}$-acetylcysteine on caerulein-induced pancreatitis and associated liver injury in rats. World $\mathrm{J}$ Gastroenterol 2006; 12: 259-264.

12. Leindler L, Morschl E, László F et al. Importance of cytokines, nitric oxide, and apoptosis in the pathological process of necrotizing pancreatitis in rats. Pancreas 2004; 29: 157-161.

13. Chen P, Yuan Y, Wang S, Zhan L, Xu J. Captopril, an Angiotensinconverting enzyme inhibitor, attenuates the severity of acute pancreatitis in rats by reducing expression of matrix metalloproteinase 9. Tohoku $\mathrm{J}$ Exp Med 2006; 209: 99-107.

14. Klar E, Schratt W, Foitzik T, Buhr H, Herfarth C, Messmer K. Impact of microcirculatory flow pattern changes on the development of acute edematous and necrotizing pancreatitis in rabbit pancreas. Dig Dis Sci 1994; 39: 2639-2644.

15. Keck T, Werner J, Banafsche $\mathbf{R}$ et al. Oxygen radicals promote ICAM-1 expression and microcirculatory disturbances in experimental acute pancreatitis. Pancreatology 2003; 3: 156-63.

16. Kusterer K, Poschmann T, Friedemann A, Enghofer M, Zendler S, Usadel KH. Arterial constriction, ischemia-reperfusion, and leukocyte adherence in acute pancreatitis. Am J Physiol 1993; 265: 165-171.
17. Foitzik T, Eibl G, Hotz Hg, Faulhaber J, Kirchengast M, Buhr H. Endothelin receptor blockade in severe acute pancreatitis leads to systemic enhancement of microcirculation, stabilization of capillary permeability, and improved survival rates. Surgery 2000; 127: 399-407.

18. Dobosz M, Hac S, Mionskowska L, Dymecki D, Dobrowolski S, Wajda Z. Organ microcirculatory disturbances in experimental acute pancreatitis. A role of nitric oxide. Physiol Res 2005; 54: 363-368.

19. Matull WR, Pereira SP, O'Donohue JW. Biochemical markers of acute pancreatitis. J Clin Pathol 2006; 59: 340-344.

20. Hartwig W, Jimenez RE, Werner J, Lewandrowski KB, Warshaw AL, Fernández-del Castillo C. Interstitial trypsinogen release and its relevance to the transformation of mild into necrotizing pancreatitis in rats. Gastroenterology 1999; 117: 717-725.

21. Osman MO, Jensen SL. Acute pancreatitis: The pathophysiological role of cytokines and integrins. New trends for treatment? Dig Surg 1999; 16: 347-362.

22. Laveda R, Martinez J, Munoz C et al. Different profile of cytokine synthesis according to the severity of acute pancreatitis. World J Gastroenterol 2005; 11: 5309-5313.

23. Tsujimoto M, Yokota S, Vilcek J, Weissmann G. Tumor necrosis factor provokes superoxide generation from neutrophils. Biochem Biophys Res 1986; 37: 1094-1099.

24. Frossard JL, Steer ML, Pastor CM. Acute pancreatitis. Lancet 2008; 371: $143-152$.

25. Kelly DM, McEntee GP, McGeeney KF, Fitzpatrick JM. Microvasculature of the pancreas, liver, and kidney in cerulean-induced pancreatitis. Arch Surg 1993; 128: 293-295.

26. Kelly DM, McEntee GP, Delaney C, McGeeney KF, Fitzpatrick JM. Temporal relationship of acinar and microvascular changes in caeruleininduced pancreatitis. Br J Surg 1993; 80: 1174-1176.

27. Takeyama Y. Significance of apoptosis cell death in systemic complications with severe acute pancreatic. J Gastroenterol 2005; 40: 1-10.

28. Yamada T, Kuno A, Masuda $K$ et al. Candesartan, an angiotensin II receptor antagonist, suppresses pancreatic inflammation and fibrosis in rats. J Pharmacol Exp Ther 2003; 307: 17-23.

Received February 19, 2014. Accepted February 26, 2014. 